San Jose State University

SJSU ScholarWorks

Faculty Publications

Health Science and Recreation

7-15-2019

\title{
Medical diaspora: an underused entity in low- and middle-income countries' health system development
}

\author{
Seble Frehywot \\ Milken Institute School of Public Health, The George Washington University \\ Chulwoo Park \\ Milken Institute School of Public Health, The George Washington University, charles.park@sjsu.edu \\ Alexandra Infanzon \\ Lenoir-Rhyne University
}

Follow this and additional works at: https://scholarworks.sjsu.edu/healthsci_rec_pub

Part of the Health and Medical Administration Commons, and the Other Public Health Commons

\section{Recommended Citation}

Seble Frehywot, Chulwoo Park, and Alexandra Infanzon. "Medical diaspora: an underused entity in lowand middle-income countries' health system development" Human Resources for Health (2019).

https://doi.org/10.1186/s12960-019-0393-1

This Article is brought to you for free and open access by the Health Science and Recreation at SJSU

ScholarWorks. It has been accepted for inclusion in Faculty Publications by an authorized administrator of SJSU

ScholarWorks. For more information, please contact scholarworks@sjsu.edu. 


\title{
Medical diaspora: an underused entity in low- and middle-income countries' health system development
}

\author{
Seble Frehywot ${ }^{1 *} \mathbb{D}$, Chulwoo Park ${ }^{1}$ and Alexandra Infanzon ${ }^{2}$
}

\begin{abstract}
Background: At present, over 215 million people live outside their countries of birth, many of which are referred to as diaspora - those that live in host countries but maintain strong sentimental and material links with their countries of origin, their homelands. The critical shortage of Human Resources for Health $(\mathrm{HRH})$ in many developing countries remains a barrier to attaining their health system goals. Usage of medical diaspora can be one way to meet this need. A growing number of policy-makers have come to acknowledge that medical diaspora can play a vital role in the development of their homeland's health workforce capacity. To date, no inventory of low- and middle-income countries (LMIC) medical diaspora organizations has been done. This paper intends to develop an inventory that is as complete as possible, of the names of the LMIC medical diaspora organizations in the United States of America, the United Kingdom, Canada, and Australia and addresses their interests and roles in building the health system of their country of origin.
\end{abstract}

Methods: The researchers utilized six steps for their research methodology: (1) development of rationale for choosing the four destination countries (the United States of America, the United Kingdom, Canada, and Australia); (2) identification of low- and middle-income countries (LMIC); (3) web search for the name of LMIC medical diaspora organization in the United States of America, the United Kingdom, Canada, and Australia through the search engines of PubMed, Scopus, Google, Google Scholar, and LexisNexis; (4) development of inclusion and exclusion criteria and creation of a medical diaspora organizations' inventory list (Table 1) and corresponding maps (Figures 1, 2, and 3). Using decision criteria, reviewers narrowed the number to a final 89 organizations; (5) synthesis of information to collect the general as well as the unique roles the medical diaspora organizations play in building health systems; and (6) developing inventory of respective LMIC governments' diaspora offices (Table 2) to identify units/departments that facilitate diaspora's work.

Result: In total, the authors found 89 medical diaspora organizations in 4 main countries: in the United States of America 60, in the United Kingdom 24, in Australia 3, and in Canada 2. These medical diaspora organizations tend to have three focuses: providing healthcare services, training, and when needed humanitarian aid to their home country; creating a social or professional network of migrant physicians (i.e., simply to bring together people with an ethnic and professional commonality) and; supplying improved and culturally sensitive healthcare to the migrant population within the host country. Sixty-eight LMIC countries have established a diaspora office within their government office. It is also equally important to note that many policy-makers may lack knowledge of models for medical diaspora engagement or of valuable lessons learned by other governments about working with diaspora.

Conclusions: The medical diaspora remains an underutilized resource in both health systems policy formulation and program implementation.

Keywords: Medical diaspora, Low- and middle-income countries, Capacity development

\footnotetext{
* Correspondence: seblelf@gwu.edu

${ }^{1}$ Milken Institute School of Public Health, The George Washington University,

950 New Hampshire Ave. NW, Washington DC 20052, United States of America

Full list of author information is available at the end of the article
}

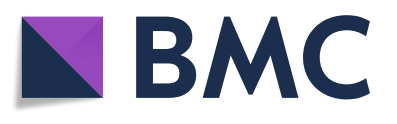

(c) The Author(s). 2019 Open Access This article is distributed under the terms of the Creative Commons Attribution 4.0 International License (http://creativecommons.org/licenses/by/4.0/), which permits unrestricted use, distribution, and reproduction in any medium, provided you give appropriate credit to the original author(s) and the source, provide a link to the Creative Commons license, and indicate if changes were made. The Creative Commons Public Domain Dedication waiver (http://creativecommons.org/publicdomain/zero/1.0/) applies to the data made available in this article, unless otherwise stated. 


\section{Background}

There are various definitions of the term diaspora, many of which have evolved over time. Once exclusively used in a context-bound way, describing that of Jewish history and the plight of Jewish people being dispersed "among the nations," the folk term became generalized on a grand (global) scale in the late twentieth century. Since the 1970s, "diaspora" has been increasingly used to denote people living far away from their ancestral or former homeland, which is reflected in Sheffer's definition of the modern diaspora as "ethnic minority groups of migrant origins residing and acting in host countries but maintaining strong sentimental and material links with their countries of origin, their homelands" [1]. For many developing countries, remittances from the diaspora are an important source of foreign exchange, surpassing earnings from major exports, and covering a substantial portion of imports [2]. The history of the semantics of the term "diaspora" points to several changes of the term's meaning. As is fairly well known, "diaspora" is a Greek term. The noun dÝaw $o €$ is a derivation from the Greek composite verb "dia-" and "speirein" (dÝaw e $€ \hat{Y}$ eÝn, infinitive), adopting meanings of "to scatter," "to spread," or "to disperse" [3]. For the purpose of this paper, medical diaspora is defined by the authors as physicians that have migrated from their country of origin to another country.

The Sustainable Development Goals (SDGs), which build upon the Millennium Development Goals (MDGs), emphasize a cross-thematic framework in the post-2015 development agenda [4]. Although health is not explicitly mentioned, the SDGs demonstrate the important linkages between health and development. To achieve these ambitious targets, the international community around the globe has committed to investing heavily in health systems to support these efforts, particularly in training and retention of health workers. However, the critical shortage of Human Resources for Health (HRH) in many developing countries remains a barrier to optimizing these efforts [5, 6]. Usage of medical diaspora can be one way to meet this need. Diaspora groups possess vital knowledge of the social and cultural context of their homelands. Over the past few years, the contributions of migrants and diaspora to sustainable development in their countries of origin and destination have been acknowledged by the 2030 Agenda for Sustainable Development, the New York Declaration for Refugees and Migrants and the Summits of the Global Forum on Migration and Development [7]. In addition, countries may want to advance the utilization of the medical diaspora as a way of countering the negative impacts created by the medical migration. Return migrants, in particular, bring back their skills and work experience from abroad boosting productivity [8].

To date, no inventory of low- and middle-income countries' (LMIC) medical diaspora organizations, based on their location, specialty of work, and the prospect and feasibility of using them for the capacity development of the health workforce in LMIC has been done. The authors set out with the research question of "do medical diaspora organizations exist in these four developed countries and if they do, what are the key roles of these organizations?"

Based on this, this paper aims to develop an inventory that is as complete as possible, of the roles of the LMIC medical diaspora organizations in building the health care system of their country of origin.

\section{Methods}

The method for the paper is comprised of six steps:

1. Development of rationale for choosing the four destination countries (the United States of America, the United Kingdom, Canada, and Australia)

From the outset, for two main reasons, the focus of this research has been on four anglophone destination countries: the United States of America, the United Kingdom, Canada, and Australia. This is because of two reasons. First, in many cases medical diaspora are actively recruited by the wealthy nations of Europe, North America, Australia, and elsewhere [9], and second specifically, because international medical graduates constitute between 23 and 28 percent of physicians in the United States of America, the United Kingdom, Canada, and Australia, and lower-income countries supply between 40 and 75\% of these international medical graduates [10].

2. Identification of low- and middle-income countries

This list was obtained from the World Bank website [11].

\section{Web search}

For each LMIC country, search for the name of medical diaspora organization in the United States, the United Kingdom, Canada, and Australia was conducted through PubMed, Scopus, Google, Google Scholar, and LexisNexis. Each individual LMIC country was connected with the search terms of medical diaspora organization, medical diaspora engagement, medical diaspora services, medical diaspora initiatives, and medical diaspora contributions using Boolean Operation "AND" and "OR." Through this, a list of 130 medical diaspora organizations was identified.

4. Development of inclusion and exclusion criteria and creation of a medical diaspora organizations' inventory list and corresponding maps 
By using inclusion and exclusion criteria, the list of 130 medical diaspora organizations was narrowed down to 89 medical diaspora organizations.

\section{- Inclusion criteria:}

Medical diaspora organizations that are located in the following four countries: Australia, Canada, the United Kingdom, and the United States of America.

Medical diaspora organizations' members are from a specific LMIC country.

The organization mainly consists of medical doctors.

The organization name clearly includes word associated with the medical profession.

The medical diaspora organizations headquarter office has an active webpage and indicates the actual address of the headquarter office.

\section{- Exclusion criteria:}

Biomedical science, scientist, or engineer diaspora organizations

Nurse or pharmacist diaspora organizations

Organizations of regions or chapters: Many of organizations had branches across the country, such as in the name of regions or chapters, but it was worth including only the representative one, such as headquarter, to maintain the simplicity of the medical diaspora organization list (see Table 1).

\section{- Exception:}

There are four medical diaspora organizations that have been included because they did not satisfy all inclusion criteria: Association of Philippine Physicians in America, Philippine Medical Association in America, Sri Lanka Medical Association of North America, and Vietnamese Physicians Association. Although the headquarters of those organizations had no website, there were a number of their chapters with viable websites across the United States of America.

Once the list was finalized, an inventory list of the medical diaspora organizations in the United States of America, the United Kingdom, Canada, and Australia was developed together with a corresponding map (see Table 1 and Figs. 1, 2, and 3).

\section{Synthesis of information}

Based on the research question, each medical diaspora website and the articles we found about it was searched to collect the work that the particular institution engages in and the general as well as the unique roles the medical diaspora organization plays in building health systems.
6. Developing inventory of respective LMIC governments' diaspora offices

For each LMIC country, a search of the respective LMIC Ministry of Foreign Affairs sites (or its equivalent) was conducted to identify the existence, contact information and details of government units or departments that facilitate diaspora's work. A per LMIC country inventory list of this units was created (see Table 2).

\section{Results}

In total, we found 89 medical diaspora organizations: 60 in the United States of America (US), 24 in the United Kingdom (UK), 3 in Australia, and 2 in Canada. Most of them are based in the United States of America., followed by the United Kingdom, Australia, and Canada, while the others work on an international level [12] (see Table 1 and Figs. 1, 2, and 3). Moreover, a total of 41 LMIC countries of origin was found among which those that originated from Asia were 21, from Africa 8, from the Americas 8, and from Europe 4 (Table 1):

- Asia (21): Afghanistan, Armenia, Bangladesh, Burma, Cambodia, China, India, Iran, Iraq, Israel, Lebanon, Myanmar, Nepal, Pakistan, Philippines, Russia, Sri Lanka, Syria, Taiwan, Thailand, and Vietnam

- Africa (8): Cameroon, Egypt, Ethiopia, Ghana, Nigeria, Sierra Leone, Sudan, and Tanzania

- America (8): Argentina, Bolivia, Colombia, Dominican Republic, Haiti, Nicaragua, Peru, and Venezuela

- Europe (4): Albania, Romania, Serbia, and Ukraine

\section{Common attributes}

Improving medical resources in their home country

The common attribute shared by all medical diaspora organizations is the desire to improve medical resources in their home country, including building medical facilities in their home country. Almost all migrant health workers have professional ties with their countries of origin supporting health, education, and social structures, felt indebted to their countries of origin, felt obliged to help as they were once granted scholarships or training opportunities, and thus, wanted to improve life in their countries of origin [13]. The level of contribution of each medical diaspora organization or individual varies. For instance, while Abdalla et al. (2016) reported that the effectiveness of the Sudanese medial diaspora was "small magnitude, infrequent and not well organized [14]," Nwadiuko et al. (2016) concluded that U.S.-based Nigerian physicians' strong belief in effectiveness of Nigerian medical agencies would contribute to medical service trips to Nigeria [15]. In another instance, 
Table 1 The list of medical diaspora organizations

\begin{tabular}{|c|c|}
\hline Medical diaspora organizations (in alphabetical order) & URL site \\
\hline 1. Academy of Persian American Physicians & http://persianphysician.org \\
\hline 2. Afghan Medical Association of America & http://www.afghanmed.org \\
\hline 3. Afghan Medical Professionals Association of America & http://www.ampaa.org \\
\hline 4. Albanian American Medical Society, Inc. & https://www.albamedsociety.org \\
\hline 5. American Association of Cardiologists of Indian Origin & http://www.aacio.org \\
\hline 6. American Association of Physicians of Indian Origin & https://aapiusa.org \\
\hline 7. American Board Certified Doctors for Egypt & http://www.doctorsforegypt.com \\
\hline 8. American Lebanese Medical Association & https://www.almamater.org \\
\hline 9. American Nepal Medical Foundation & https://www.anmf.org \\
\hline 10. American Society of Indian Plastic Surgeons & $\begin{array}{l}\text { https://www.facebook.com/American-Society-of-Indian-Plastic-Surgeons- } \\
189293321104812\end{array}$ \\
\hline 11. American Ukrainian Medical Foundation & http://aumf.net \\
\hline 12. Argentine-American Medical Society & http://www.aams.us \\
\hline 13. Armenian American Medical Society & https://aamsc.org \\
\hline 14. Armenian Medical Society of Great Britain & http://www.accc.org.uk \\
\hline 15. Association of Afghan Healthcare Professionals UK & http://aahpuk.org \\
\hline 16. Association of Chinese American Physicians & http://www.acaponline.org \\
\hline 17. Association of Haitian Physicians Abroad & http://www.amhe.org/index.html \\
\hline 18. Association of Kerala Medical Graduates & http://www.akmg.org \\
\hline 19. Association of Nepali Physicians in America & http://anpa-usa.org \\
\hline 20. Association of Nigerian Physicians in the Americas & https://anpa.org \\
\hline 21. Association of Pakistani Physicians and Surgeons of the UK & http://appsuk.org \\
\hline
\end{tabular}

22. Association of Philippine Physicians in America*

23. Association of Physicians of Pakistani Descent of North America

24. Australia Myanmar Medical Association

Although this representative organization has no website, there are a number of its chapters in each state.

http://appna.org

http://www.au-mma.org

https://www.bmana.org

http://www.bmsuk.org.uk

http://www.bolivianamericanmedicalsociety.com

https://www.bapio.co.uk

https://www.facebook.com/BIMAUK

http://www.britishima.org

http://www.bamausa.org

https://www.facebook.com/BDDAUK/ref=page_internal

https://www.facebook.com/Burmese-Medical-Association-Australia-BMAA10150140888940538

http://bma-na.com

https://www.chpaa.org

https://www.camdocuk.org/home

http://canpad.org

http://chineseamericanmedicalsociety.cloverpad.org

http://www.caps-ca.org

http://www.dmanewyork.com

http://www.e-ama.org

http://www.egyptianamericanms.com 
Table 1 The list of medical diaspora organizations (Continued)

Medical diaspora organizations (in alphabetical order)
43. Egyptian Association for American Medical Training and Research
44. Egyptian Medical Society UK
45. Ethiopian North American Health Professionals Association
46. Ghana Physicians and Surgeons Foundation
47. Ghanaian Doctors \& Dentists Association
48. Iranian American Medical Association
49. Iranian Medical Society
50. Iranian Medical Society UK
51. Iranian-American Medical Society of Greater Washington
(Iranian Medical \& Dental Society of the Greater Wash-Balt Metro Area)
52. Iraqi Medical Association UK

53. Iraqi Medical Sciences Association USA

54. Medical Associations of Nigerians Across Great Britain

55. Myanmar American Medical Education Society

56. Nepalese Doctors Association

57. Nicaraguan American Medical Association

58. Nigeria American Medical Foundation International

59. North American Taiwanese Medical Association

60. Northern Indian Medical \& Dental Association of Canada

61. Organization of Sierra Leonean Healthcare Professionals Abroad

62. Pakistan Medical Association UK

63. People To People (Ethiopia)

64. Peruvian American Medical Society

65. Philippine Medical Association in America*

66. Rajasthan Medical Alumni Association

67. Romanian Medical Association of America

68. Romanian Medical Society UK

69. Russian American Medical Association

70. Serbian American Medical and Dental Society

71. Serbian American Medical Association

72. Society of Philippine Surgeons in America

73. South Australian Sri Lankan Doctors Association

74. Sri Lanka Medical Association of North America*

75. Sri Lankan Medical and Dental Association of the UK

76. Sudanese American Medical Association

77. Sudanese Junior Doctors Association UK

78. Sudanese Medical Association UK and Ireland

79. Syrian American Medical Society Foundation

80. Syrian British Medical Society

81. Tanzania UK Healthcare Diaspora Association

82. Thai Physicians Association of America

83. Ukrainian Medical Association of North America

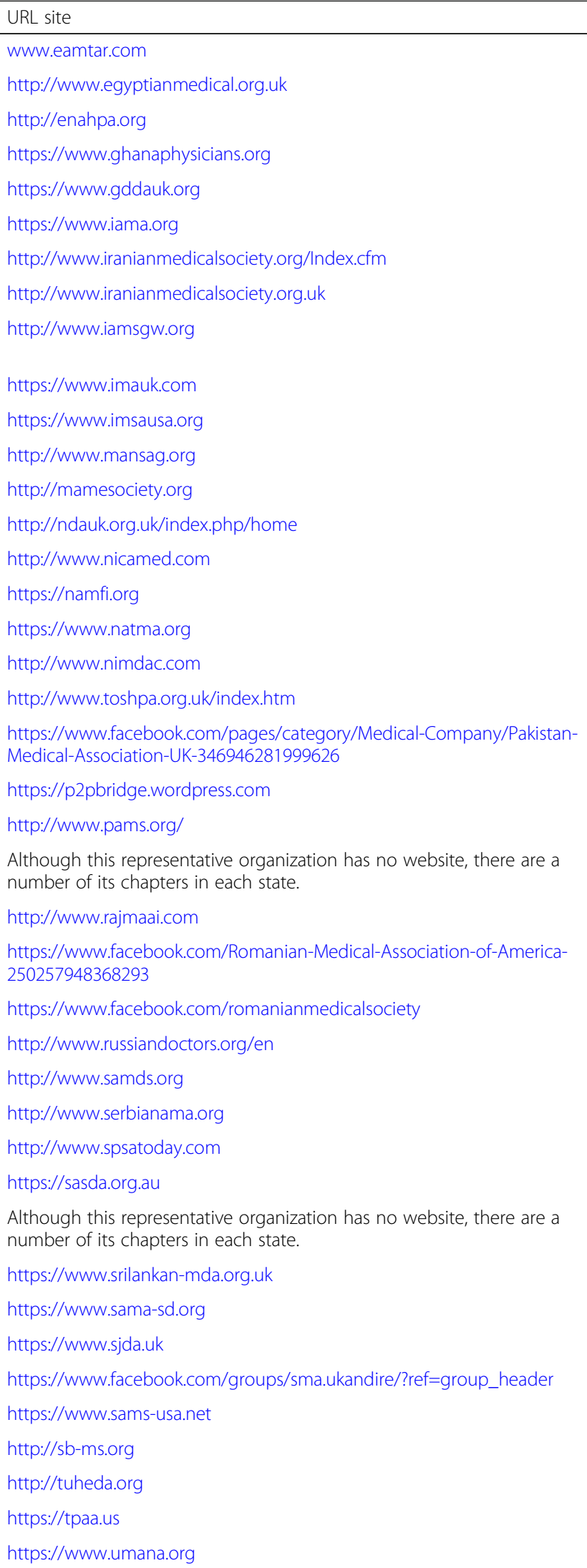

https://p2pbridge.wordpress.com

http://www.pams.org/

Although this representative organization has no website, there are a number of its chapters in each state.

http://www.rajmaai.com

https://www.facebook.com/Romanian-Medical-Association-of-America250257948368293

https://www.facebook.com/romanianmedicalsociety

http://www.russiandoctors.org/en

http://www.samds.org

http://www.serbianama.org

http://www.spsatoday.com

https://sasda.org.au

Although this representative organization has no website, there are a number of its chapters in each state.

https://www.srilankan-mda.org.uk

https://www.sama-sd.org

https://www.sjda.uk

https://www.facebook.com/groups/sma.ukandire/?ref=group_header

https://www.sams-usa.net

http://sb-ms.org

http://tuheda.org

https://tpaa.us

https://www.umana.org 
Table 1 The list of medical diaspora organizations (Continued)

\begin{tabular}{ll}
\hline Medical diaspora organizations (in alphabetical order) & URL site \\
\hline 84. Ukrainian Medical Association of the UK & http://www.umauk.com \\
$\begin{array}{l}\text { 85. United States Colombian Medical Association } \\
\text { 86. University of Santo Tomas Medical Alumni Association in America } \\
\text { (Philippine) }\end{array}$ & https://uscma.wordpress.com \\
$\begin{array}{l}\text { 87. Venezuelan American Medical Association } \\
\text { 88. Vietnamese American Medical Association }\end{array}$ & https://www.vamainfo.com \\
89. Vietnamese Physicians Association* & http://www.vamausa.org \\
& Although this representative organization has no website, there are a \\
& number of its chapters in each state.
\end{tabular}

Wojczewski et al. (2015) have shown that African medical doctors who left their home countries as refugees cannot engage in any form of return initiatives, either short or long-term [13].

\section{African countries}

The Nigerian American Medical Foundation International (NAMFI) aims to provide world-class tertiary medical care on Nigerian soil through a gradual threephase program of a sustainable 20-year development plan [16]. The Sudanese Medical Association UK and Ireland (SMA) aims to provide advice and support to the colleagues responsible for health services, medical and health education in Sudan, and contribute to the transfer of modern technology, expertise, and scientific updates to Sudan through cooperation with professional bodies and health authorities in the country [17]. The diaspora organizations collaborate with health professionals in their home country to provide a pathway for the exchange of information between the countries. The

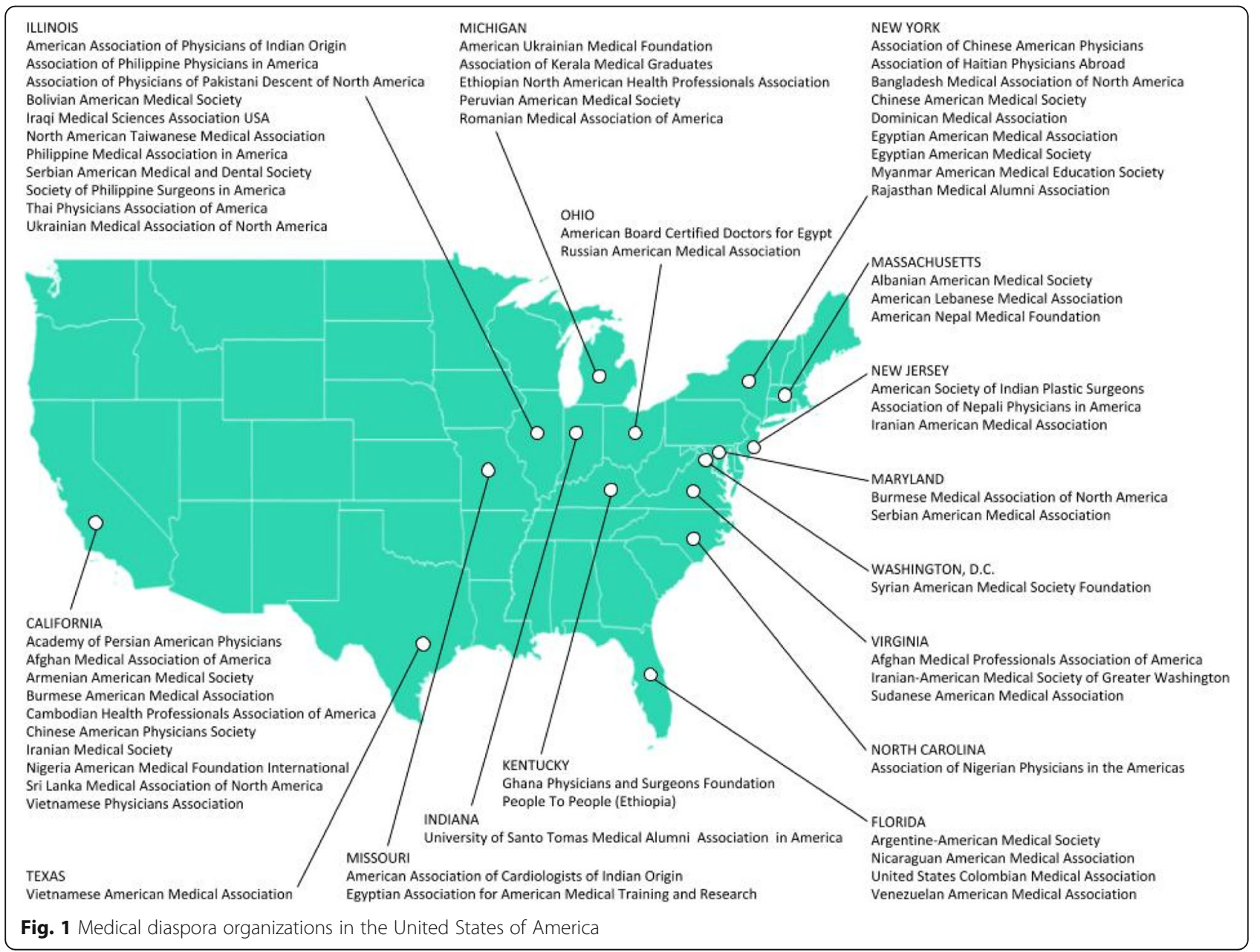




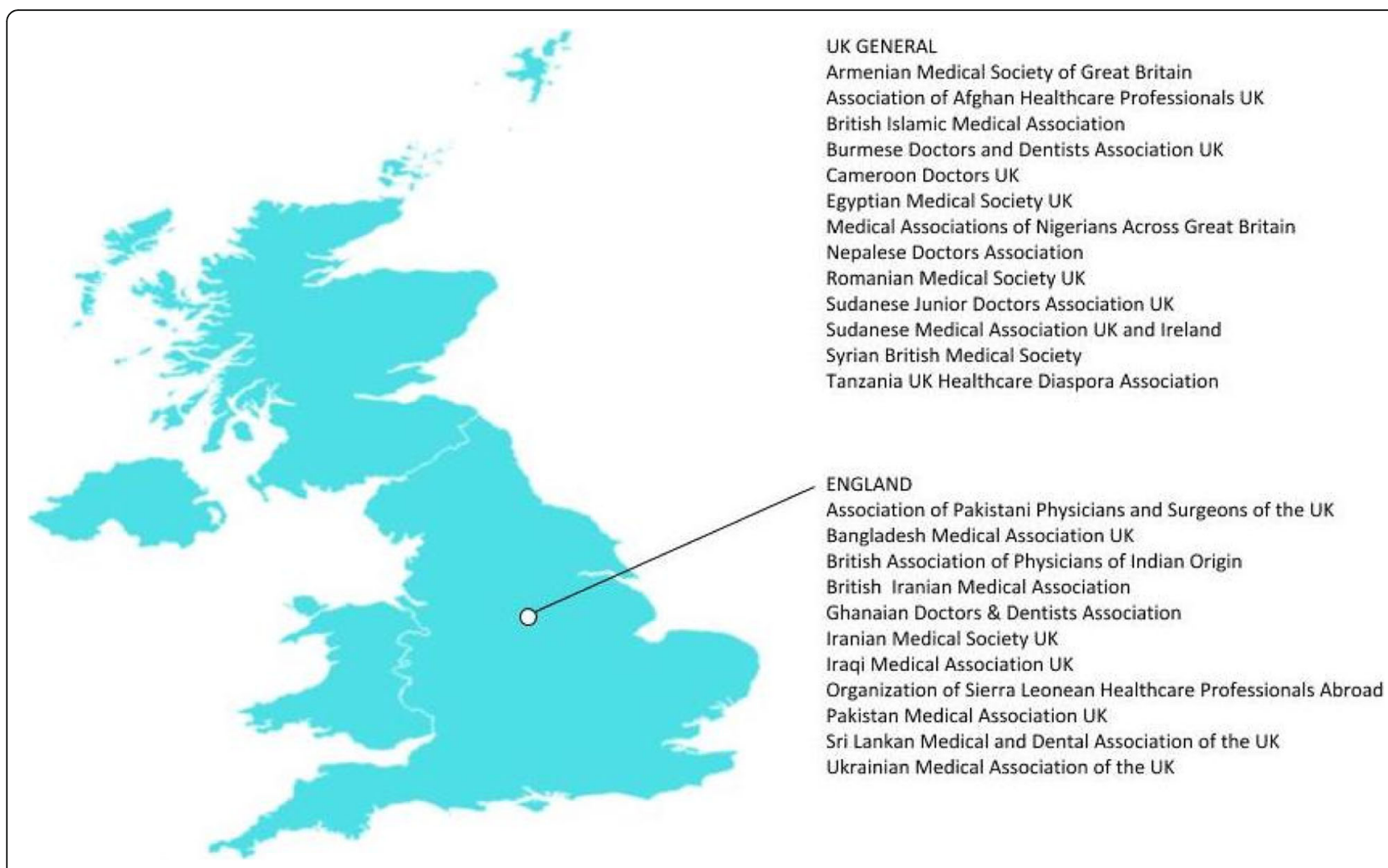

Fig. 2 Medical diaspora organizations in the United Kingdom

Ethiopian North American Health Professionals Association achieves this by using distance learning, providing medical training, and sponsoring international medical fellowships for Ethiopian health providers [18]. Similarly, the Ghana Physicians and Surgeons Foundation of North America (GPSF) aims to provide quality training for healthcare professionals in Ghana by providing subscriptions to world-class medical journals, superb online educational tools, and teaching materials to medical colleges in Ghana [19].

\section{Asian countries}

The American Association of Physicians of Indian Origin (AAPI) has set up multiple AAPI clinics in India, which offer free and compassionate health care [20]. The Afghan Medical Professionals Association of America

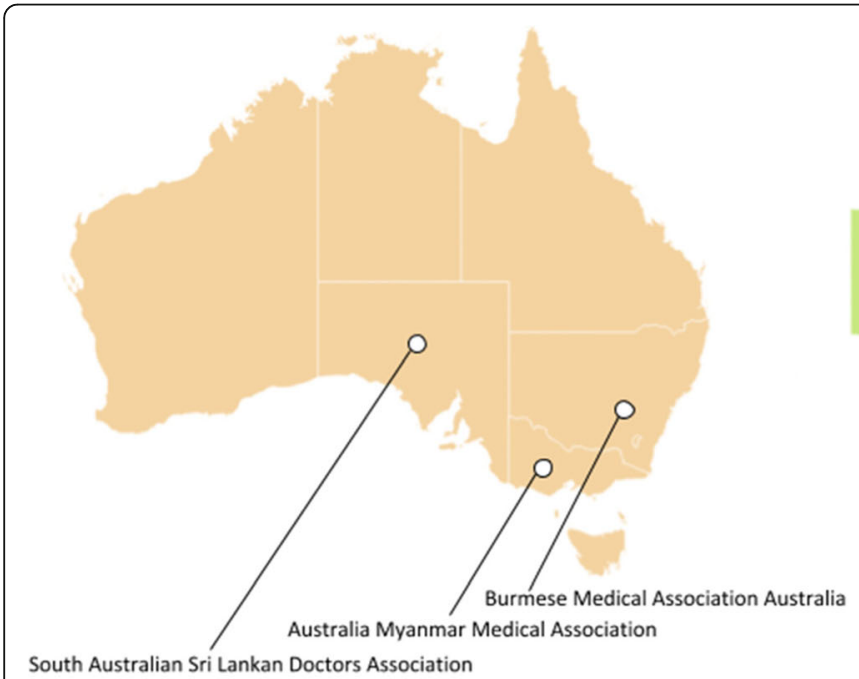

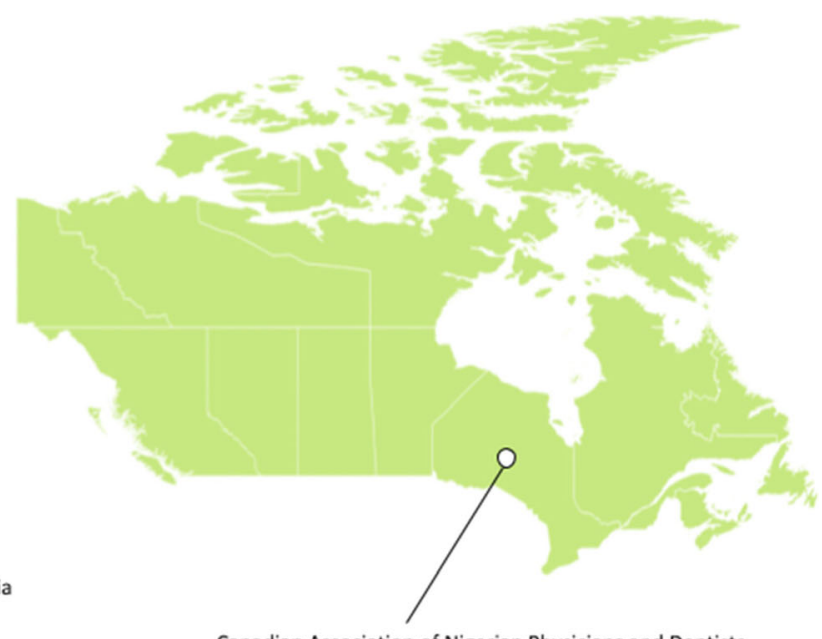

Canadian Association of Nigerian Physicians and Dentists Northern Indian Medical \& Dental Association of Canada

Fig. 3 Medical diaspora organizations in Australia and Canada 
Table 2 Table of country diaspora offices within the respective Ministry of Foreign Affairs

\begin{tabular}{|c|c|c|c|}
\hline Country & Engagement office & Website & Year establishe \\
\hline Afghanistan & & & Not available \\
\hline Albania & Ministry of Foreign Affairs, Diaspora Department & & Not available \\
\hline Algeria & $\begin{array}{l}\text { Ministry of National Solidarity, Family and the } \\
\text { National Community Abroad }\end{array}$ & & Not available \\
\hline American Samoa & & & Not available \\
\hline Angola & $\begin{array}{l}\text { Ministry of Foreign Affairs } \\
\text { Institute of the Angolan Communities Abroad } \\
\text { and Consulate Affairs }\end{array}$ & http://www.mirex.gov.ao & Not available \\
\hline Armenia & Ministry of Diaspora & & Not available \\
\hline Azerbaijan & State Committee on Affairs of the Diaspora & $\begin{array}{l}\text { http://www.azerbaijans.com/content_556_en. } \\
\text { html }\end{array}$ & 2002 \\
\hline Bangladesh & $\begin{array}{l}\text { Ministry of Expatriates' Welfare and Overseas } \\
\text { Employment (MEWOE) }\end{array}$ & http://www.probashi.gov.bd & 2001 \\
\hline \multicolumn{4}{|l|}{ Belarus } \\
\hline \multicolumn{4}{|l|}{ Belize } \\
\hline Benin & $\begin{array}{l}\text { Ministry for Foreign Affairs, African Integration, } \\
\text { the Francophone Community, and Beninese } \\
\text { Abroad }\end{array}$ & Not available & Not available \\
\hline Bhutan & & & Not available \\
\hline Bolivia (Plurinational State of) & & & Not available \\
\hline Bosnia Herzegovina & $\begin{array}{l}\text { Ministry of Human Rights and Refugees: } \\
\text { Department of Diaspora }\end{array}$ & $\begin{array}{l}\text { http://www.mhrr.gov.ba/iseljenistvo/aktuelnosti/ } \\
\text { Archive.aspx?langTag=bs-BA\&template_id=12 } \\
\text { 8\&pagelndex=1 }\end{array}$ & Not available \\
\hline Botswana & & & Not available \\
\hline Brazil & $\begin{array}{l}\text { Ministry of Foreign Affairs, Undersecretary } \\
\text { General for Brazilian Communities Abroad }\end{array}$ & http://www.brasileirosnomundo.itamaraty.gov.br & Not available \\
\hline Bulgaria & State Agency for Bulgarians Abroad & http://www.aba.government.bg/?show=10 & 2000 \\
\hline Burkina Faso & $\begin{array}{l}\text { Ministere Des Affaires Etrangres Et De La } \\
\text { Cooperation Regionale }\end{array}$ & http://www.mae.gov.bf & 2007 \\
\hline Burundi & Ministry of Foreign Affairs, Directorate of Diaspora & Not available & Not available \\
\hline Cambodia & & Not available & Not available \\
\hline Cameroon & Not available & Not available & Not available \\
\hline Cape Verde & Not available & Not available & Not available \\
\hline Central African Republic & Not available & Not available & Not available \\
\hline Chad & Not available & Not available & Not available \\
\hline China & $\begin{array}{l}\text { State Council, Overseas Chinese Affairs Office of } \\
\text { the State Council; Overseas Chinese Affairs } \\
\text { Committee } \\
\text { The Overseas Chinese Affairs Office (SOCAO) of } \\
\text { Shanghai Municipal People's Government }\end{array}$ & http://www.overseas.sh.cn & $\begin{array}{l}1978, \text { renamed } \\
1980\end{array}$ \\
\hline Colombia & $\begin{array}{l}\text { Colombia Nos Une, a program of the Bureau of } \\
\text { Consular Affairs and Colombian Communities } \\
\text { Abroad in the Ministry of Foreign Affairs }\end{array}$ & http://www.redescolombia.org & Not available \\
\hline Comoros & $\begin{array}{l}\text { Ministry of External Relations and Cooperation of } \\
\text { the Diaspora }\end{array}$ & & Not available \\
\hline Congo, Dem. Rep. of & & & Not available \\
\hline Congo, Rep. of & & & Not available \\
\hline Costa Rica & & & Not available \\
\hline Cote D'Ivoire & & & Not available \\
\hline Cuba & & & Not available \\
\hline
\end{tabular}


Table 2 Table of country diaspora offices within the respective Ministry of Foreign Affairs (Continued)

\begin{tabular}{|c|c|c|c|}
\hline Country & Engagement office & Website & Year establishe \\
\hline Djibouti & & & Not available \\
\hline Dominica & $\begin{array}{l}\text { Ministry of Trade, Industry, Consumer, Diaspora } \\
\text { Affairs }\end{array}$ & $\begin{array}{l}\text { http://www.dominica.gov.dm/employment-trade- } \\
\text { industry-and-diaspora-affairs }\end{array}$ & Not available \\
\hline Dominican Republic & $\begin{array}{l}\text { National Presidential Council for Dominican } \\
\text { Communities Abroad }\end{array}$ & & Not available \\
\hline Ecuador & & & Not available \\
\hline Egypt & $\begin{array}{l}\text { Ministry of Manpower and Emigration, } \\
\text { Emigration Sector } \\
\text { Higher Committee on Migration }\end{array}$ & & Not available \\
\hline El Salvador & $\begin{array}{l}\text { Ministry of Foreign Affairs, Vice Ministry for } \\
\text { Salvadorans Abroad } \\
\text { National Secretariat for Migrants (various states) }\end{array}$ & http://www.rree.gob.sv & 2004 \\
\hline Eritrea & $\begin{array}{l}\text { Ministry of Foreign Affairs, Department of } \\
\text { Eritreans Abroad }\end{array}$ & $\begin{array}{l}\text { http://www.mfa.gov.et/Diaspora/more. } \\
\text { php?newsid=7 }\end{array}$ & Late 1990's \\
\hline Ethiopia & $\begin{array}{l}\text { Ministry of Foreign Affairs, Diaspora Affairs } \\
\text { Directorate General; Ministry of Capacity Building, } \\
\text { Diaspora Coordinating Office }\end{array}$ & $\begin{array}{l}\text { http://www.mfa.gov.et/Diaspora/more. } \\
\text { php?newsid=7 }\end{array}$ & 2002 \\
\hline Fiji & & & Not available \\
\hline Gabon & & & Not available \\
\hline The Gambia & $\begin{array}{l}\text { Ministry of Foreign Affairs, International } \\
\text { Cooperation \& Gambians Abroad }\end{array}$ & $\begin{array}{l}\text { http://www.mofa.gov.gm/index.php?option= } \\
\text { com_content\&view=article\&id=58\&ltemid=83 }\end{array}$ & Not available \\
\hline Georgia & State Ministry for Diaspora Issues & http://diaspora.gov.ge/index.php?lang_id=ENG & 2008 \\
\hline Ghana & Ministry of Interior, National Migration Unit & http://www.mfa.gov.gh/index.php?id=1 & 2003 \\
\hline Grenada & $\begin{array}{l}\text { Office of Diaspora Affairs, division of Ministry of } \\
\text { Foreign Affairs }\end{array}$ & $\begin{array}{l}\text { http://www.oxonwebmaster.com/mfa/index. } \\
\text { php?q=diaspora }\end{array}$ & 2009 \\
\hline Guatemala & National Council for Migrants from Guatemala & & Not available \\
\hline Guinea & Ministry of Foreign Affairs and Guineans Abroad & $\begin{array}{l}\text { No website but phone number was found: } \\
\text { Phone }+22430451270\end{array}$ & Not available \\
\hline Guinea-Bissau & & & Not available \\
\hline Guyana & Ministry of Foreign Affairs Diaspora Unit & $\begin{array}{l}\text { http://www.minfor.gov.gy/index.php?option= } \\
\text { com_content\&task=view\&id=70\&ltemid=120 }\end{array}$ & Not available \\
\hline Haiti & Ministry of Haitians Living Abroad & http://mhave.gouv.ht & 1995 \\
\hline \multicolumn{4}{|l|}{ Honduras } \\
\hline India & $\begin{array}{l}\text { Ministry of Overseas Indian Affairs } \\
\text { Government of Kerala, Department of Non- } \\
\text { Resident Keralites' Affairs; Government of Gujarat, } \\
\text { Non-Resident Indian Division }\end{array}$ & http://moia.gov.in & 2004 \\
\hline Indonesia & Ministry of Manpower and Transmigration & $\begin{array}{l}\text { http://indonesia.go.id/en/ministries/ministers/ } \\
\text { ministry-of-manpower-and-transmigration/1644- } \\
\text { profile/194-kementeriann-tenaga-kerja-dan- } \\
\text { transmigrasi.html }\end{array}$ & 1983 \\
\hline \multicolumn{4}{|l|}{ Iran } \\
\hline Iraq & Ministry of Migration and Displaced & & \\
\hline Jamaica & Diaspora and Consular Affairs Office & $\begin{array}{l}\text { http://www.mfaft.gov.jm/jm/about-us/ } \\
\text { departments-units/diaspora-consular-affairs }\end{array}$ & 1993 \\
\hline Jordan & Department of Consular Affairs and Expatriates & $\begin{array}{l}\text { http://www.mfa.gov.jo/ar/\%D8\%A7\%D9\%84\% } \\
\text { D9\%82\%D8\%A7\%D8\%A6\%D9\%85\%D8\%A9\%D8\% } \\
\text { A7\%D9\%84\%D8\%B1\%D8\%A6\%D9\%8A\%D8\%B3\% } \\
\text { D9\%8A\%D8\%A9/\%D8\%A7\%D9\%84\%D8\%B5\% } \\
\text { D9\%81\%D8\%AD\%D8\%A9\%D8\%A7\%D9\%84\%D8\% } \\
\text { B1\%D8\%A6\%D9\%8A\%D8\%B3\%D9\%8A\%D8\%A9/ } \\
\text { tabid/71/Default.aspx }\end{array}$ & Not available \\
\hline
\end{tabular}


Table 2 Table of country diaspora offices within the respective Ministry of Foreign Affairs (Continued)

\begin{tabular}{|c|c|c|}
\hline Country & Engagement office & Website \\
\hline Kenya & $\begin{array}{l}\text { Ministry of Foreign Affairs: Diaspora Affairs } \\
\text { Directorate i.e. International Jobs and Diaspora } \\
\text { Office (Directorate) }\end{array}$ & $\begin{array}{l}\text { http://www.kenyaembassytlv.org.il/209618/ } \\
\text { MINISTRY-OF-FOREIGN-AFFAIRS-ON-DIASPORA }\end{array}$ \\
\hline \multicolumn{3}{|l|}{ Kiribati } \\
\hline \multicolumn{3}{|c|}{ Korea, Dem. Rep. of } \\
\hline Kosovo & "Services for Citizens" Ministry of Foreign Affairs & http://www.mfa-ks.net/?page=2,151 \\
\hline \multicolumn{3}{|c|}{ Kyrgyz Republic } \\
\hline \multicolumn{3}{|l|}{ Lao PDR } \\
\hline Lebanon & Ministry of Foreign Affairs and Emigrants & \\
\hline Lesotho & Association: Diaspora Alliance & http://lesothopretoria.com/?trade_14 \\
\hline Liberia & Ministry of states with no portfolio & $\begin{array}{l}\text { http://www.emansion.gov.lr/2content.php?sub= } \\
\text { 32\&related=21\&third=32\&pg=sp } \\
\text { http://www.mofa.gov.lr/public2/doc/EOI\%2 } \\
\text { OFOR\%20DIASPORA\%20ADVISOR(Bank\%2 } \\
\text { OComments)\%20(1).pdf }\end{array}$ \\
\hline
\end{tabular}

Year established

2007

Not available

Not available

Not available

Not available

Not available

Not available

Not available

1972

Not available

Not available

Macedonia, FYR

Agency for Emigration

Madagascar

Malawi

Ministère des Affaires Etrangères- "Diaspora and Economic Development"

Ministry of Foreign Affairs-Diaspora Services

http://mae.gov.mg/\#

Not available

http://www.foreignaffairs.gov.mw/index.php/ diaspora-services/overview

Not available

Not available

Not available

Ministry of Malians Abroad and African Integration

Consultation Framework on Migration

High Council of Malians Abroad

Mauritania

Mauritius

Mexico

Secretariat of Foreign Affairs, Sub-secretariat for North America; Institute for Mexicans Abroad

National Council on Mexican Communities

Abroad

National Coordination for State-level Migrant Affairs Offices (various states)

Consultative Council of the Institute for Mexicans Abroad

Micronesia, Federated States of

Moldova

Bureau of Inter-Ethnic Relations has a Diaspora branch

http://www.bri.gov.md/index.php?.pag=sec\&id= $122 \& \mid=e n$

http://diaspora.md

Not available

Not available

2002

Not available

2010

Not available

Not available

Ministry Charged with the Moroccan Community Residing Abroad

Interdepartmental Committees

Hassan II Foundation for Moroccans Resident

Abroad

Council on the Moroccan Community Abroad

Mozambique

Institute for Mozambican Communities Living Abroad (INACE) -a department in the Ministry of Foreign Affairs http://www.iom.int/cms/en/sites/iom/home/newsand-views/press-briefing-notes/pbn-2014b/pbnlisting/mozambique-launches-diaspora-eng.html
Not available

2014

Not available 
Table 2 Table of country diaspora offices within the respective Ministry of Foreign Affairs (Continued)

\begin{tabular}{|c|c|c|c|}
\hline Country & Engagement office & Website & Year establishe \\
\hline Namibia & & & Not available \\
\hline Nepal & & & Not available \\
\hline Nicaragua & & & Not available \\
\hline Niger & $\begin{array}{l}\text { Ministry of African Integration and Nigerians } \\
\text { Abroad } \\
\text { Committee in Charge of Migration }\end{array}$ & $\begin{array}{l}\text { http://www.messrs.ne/index.php?option=com-- } \\
\text { content\&view=article\&id=70:ministere-des-affaires- } \\
\text { etrangeres-de-lintegration-africaine-et-des- } \\
\text { nigeriens-a-lexterieur\&catid=1:liste-des-appeles-du- } \\
\text { service-civique-national-pro\&ltemid=67 }\end{array}$ & Not available \\
\hline Nigeria & $\begin{array}{l}\text { Technical Working Group and Interministerial } \\
\text { Committee on Migration }\end{array}$ & $\begin{array}{l}\text { http://www.nigeriadiasporaday.com/index.php/ } \\
\text { about/nnvs }\end{array}$ & 2002 \\
\hline Pakistan & Ministry of Overseas Pakistanis & $\begin{array}{l}\text { http://www.ophrd.gov.pk/gop/index.php?q= } \\
\text { aHROcDovLzE5Mi4xNjguNzAuMTM2L2 } \\
\text { hyZC9kZWZhdWx0LmFzCHg\%3D }\end{array}$ & Not available \\
\hline Papua New Guinea & & & Not available \\
\hline Paraguay & & & Not available \\
\hline Peru & $\begin{array}{l}\text { Ministry of Foreign Affairs, Undersecretary for } \\
\text { Peruvians Abroad } \\
\text { Advisory Council }\end{array}$ & http://www.rree.gob.pe & 2003 \\
\hline Philippines & $\begin{array}{l}\text { Philippines Department of Labor, Overseas } \\
\text { Workers Welfare Administration; Department of } \\
\text { Labor, Philippine Overseas Employment } \\
\text { Administration; Department of Foreign Affairs, } \\
\text { Office of the Undersecretary for Migrant Workers' } \\
\text { AffairsOffice of the President, Commission on } \\
\text { Filipinos Overseas; Committee on Overseas } \\
\text { Workers Affairs }\end{array}$ & $\begin{array}{l}\text { http://www.owwa.gov.ph } \\
\text { https://cfo.gov.ph/ }\end{array}$ & 1981 \\
\hline Romania & $\begin{array}{l}\text { Ministry of Foreign Affairs, Department for } \\
\text { Relations with the Romanians Abroad }\end{array}$ & http://www.dprp.gov.ro/about-us & Not available \\
\hline Russian Federation & & & Not available \\
\hline Rwanda & $\begin{array}{l}\text { Department on diaspora engagement within the } \\
\text { Ministry of External Relations and Internal } \\
\text { Cooperation (MINAFFET), Diaspora General } \\
\text { Directorate (DGD) } \\
\text { Rwandan Community Abroad (RCA) }\end{array}$ & http://www.minaffet.gov.rw/index.php?id=890 & 2008 \\
\hline
\end{tabular}

Samoa

Ministry of Senegalese Abroad

Ministry of Religion and Diaspora

Office of the President, Office of the Diaspora

Solomon Islands

Somalia

South Africa

South Sudan

Sri Lanka

St. Lucia

St. Vincent and the Grenadines

Puntland Diaspora Community Cooperation South Sudan Welfare
Not available

Not available

2003

http://www.mfa.gov.rs/en/consular-affairs/ diaspora/diaspora-general-information

http://www.diasporaaffairs.gov.sl/index. php?option=com_content\&view=article\&id= 1 \&ltemid $=2$

Not available

2013

http://www.mfa.somaligov.net

Office for Development and Partnership with the https://www.facebook.com/

OfficeforDiasporaAffairs

http://www.dfa.gov.za

Not available

Diaspora Engagement Steering Committee for

https://www.facebook.com/ southsudandiasporaforhealth

2013

Ministry of Foreign Employment Promotion and
2010

Not available

Not available 
Table 2 Table of country diaspora offices within the respective Ministry of Foreign Affairs (Continued)

\begin{tabular}{|c|c|c|c|}
\hline Country & Engagement office & Website & Year established \\
\hline Sudan & & & Not available \\
\hline Suriname & & & Not available \\
\hline Swaziland & & & Not available \\
\hline Syrian Arab Republic & Ministry of Foreign Affairs and Expatriates & http://www.moex.gov.sy & 2011 \\
\hline Tajikistan & & & Not available \\
\hline Tanzania & $\begin{array}{l}\text { Minister for Foreign Affairs and International } \\
\text { Cooperation: task force of stakeholders, which } \\
\text { involves members from his ministry, Ministry of } \\
\text { Labour and Employment, Planning Commission, } \\
\text { Public Service Management and National Statistics } \\
\text { Bureau, which will be in charge of monitoring and } \\
\text { coordinating engagement Diaspora }\end{array}$ & http://www.foreign.go.tz & Not available \\
\hline Thailand & & & Not available \\
\hline Timor-Leste & & & Not available \\
\hline Togo & $\begin{array}{l}\text { No apparent dept, but entire section of website } \\
\text { dedicated to Togolese diaspora affairs }\end{array}$ & $\begin{array}{l}\text { http://www.republicoftogo.com/Toutes-les- } \\
\text { rubriques/Diaspora }\end{array}$ & Not available \\
\hline Tonga & & & Not available \\
\hline Tunisia & $\begin{array}{l}\text { Ministry of Social Affairs, Solidarity, and Tunisians } \\
\text { Abroad }\end{array}$ & & Not available \\
\hline Turkey & & & Not available \\
\hline Turkmenistan & & & Not available \\
\hline Tuvalu & & & Not available \\
\hline Uganda & Diaspora office in the ministry of foreign affairs & $\begin{array}{l}\text { http://www.mofa.go.ug/data/smenu/16/ } \\
\text { Overview-and-Mandate.html }\end{array}$ & 2007 \\
\hline Ukraine & & & Not available \\
\hline Uzbekistan & & & Not available \\
\hline Vanuatu & & & Not available \\
\hline $\begin{array}{l}\text { Venezuela, Bolivarian } \\
\text { Republic of }\end{array}$ & & & Not available \\
\hline Vietnam & $\begin{array}{l}\text { The Committee on overseas Vietnamese affairs, } \\
\text { under the Ministry of Foreign Affairs }\end{array}$ & http://www.mofa.gov.vn/en & 2004 \\
\hline West Bank and Gaza & & & Not available \\
\hline Yemen & & & Not available \\
\hline Zambia & Office within Ministry of foreign affairs** & http://www.foreignaffairs.gov.zm/index.php & Not available \\
\hline \multirow[t]{2}{*}{ Zimbabwe } & & & Not available \\
\hline & Total: 68 & & \\
\hline
\end{tabular}

(AMPAA) aims at promoting medical education and research, providing educational assistance by means of teaching materials, training opportunities, and collaboration with Afghan medical professionals, and providing assistance in improving the quality of medical education in Afghanistan [21].

\section{European countries}

The Albanian American Medical Society aims to create and maintain a fostering educational environment between the public academic institutions in the Albanian populated territories and those in the United States of America wherein its members may meet to exchange medical knowledge and participate in continuing medical education [22]. The mission of the Armenian American Medical Society is to cultivate and develop professional, social, and friendly relations among its members, and to contribute towards the improvement of the health services rendered to the Armenian community in the Diaspora and Armenia [23]. The Ukrainian Medical Association of the United Kingdom aims at developing ties with academic and professional healthcare organizations in the United Kingdom and Ukraine to promote social, cultural, educational, and research activities [24]. The Romanian Medical Association of America encourages fostering the establishment of 
professional interactions between North American and Romanian physicians and scientists, medical societies, universities, and institutions [25].

\section{Building medical human resource capacity in their home country}

Many LMIC countries have been plagued for years with brain drain. Shortages of medical school faculty are rampant in many sub-Saharan African countries [26]. Medical diaspora organizations try to address this in one form or the other.

\section{African countries}

The People to People works to mobilize the global Ethiopian medical diaspora to play an active role in mitigating the impact of brain drain [27]. One of the goals of The Medical Association of Nigerians Across Great Britain is to support the improvement and effectiveness of Nigeria's health programs by developing and increasing the capacity of health professionals in Nigeria and overseas [28]. The Association of Nigerian Physicians in the Americas encourages the development of practical solutions to Nigerian health care problems through strategic initiatives and field activities within Nigeria [29].

\section{Asian countries}

The Nepalese Doctors' Association in the United Kingdom aims to contribute to the development of health services in Nepal by establishing greater understanding and co-operation among the Nepalese doctors in the United Kingdom [30]. The America Nepal Medical Foundation supports the Nepali people's ongoing efforts to enhance their health status and focuses on improving the quality of medical care, medical education, and medical research in Nepal [31]. The Afghan Medical Professionals Association of America aims at improving the current health status of the Afghan nation and extending medical and educational aid to Afghanistan [21]. The Bangladesh Medical Association of North America supports local immunization clinics and free clinics in Bangladesh [32]. The Syrian American Medical Society Foundation, in collaboration with local physicians in Syria, has launched training campaigns for doctors in Syria [33].

\section{New trend-web-based medical diaspora organization}

While most medical diaspora organizations have their own websites that provide an in-depth and informative introduction about them, some organizations only have Facebook pages and do not maintain their websites anymore. For example, the Sudanese Medical Association UK and Ireland, The Romanian Medical Association of America, and The Burmese Doctors and Dentists Association UK, British Iranian Medical Association are still active through Facebook pages [17, 25, 34, 35]. This new trend is utilized to effectively gather young medical doctors, scholars, and researchers to share the information with each other in the era of internet networking.

\section{Diaspora engagement: government level}

Governments around the world have been supporting diaspora institutions and create migration policy [36, 37]. As can be seen in Table 2, diaspora institutions are in the form of ministry, agency, department, council, bureau, or institute. A growing number of policy-makers have come to acknowledge that diasporas can play a vital role in the development of their homelands and some developing countries have established institutions within their countries to further facilitate ties with their diasporas systematically (see Table 2). Sixty-eight LMIC countries have established a diaspora office within their government office.

Many LMICs are developing strategies to harness the resources of diaspora groups to drive development. China and India have created an increasingly extensive diasporic infrastructure, combined with policies designed to attract investments, as well as emotionally bind the diaspora to their country of origin. For instance, the Government of India is providing incentives to its diaspora, such as the recognition of persons of Indian origin through a special ministry and arranging special conferences, and the organization of a research scientist scheme that encourages diaspora scientists to teach at Indian universities [38]. In China, diaspora engagement policy has involved aggressively recruiting the return of its highly skilled diaspora through a variety of employment and scholarship programs [39]. The approaches adopted by these Asian nations point to country-driven initiatives that are built on shared development objectives between the government and the diaspora, and underlined by comprehensive policies, administrative structures, and incentives to foster an enabling environment for mobilizing diaspora resources (expertise, investments, entrepreneurship, and corporate affiliations) around critical growth pillars [40].

Furthermore, more than 30 African countries have established diaspora-oriented institutions and ministries, and many have created permanent diaspora government offices [41] (Table 2).

These offices are often a part of their respective Ministries of Foreign Affairs, either at the ministry or the sub-ministry level. Many countries also utilize consular networks that serve as the primary mechanism to engage with diaspora.

The government of Ethiopia has established some legal status for the Ethiopian diaspora. Ethiopian diasporas who hold non-Ethiopian nationalities have been entitled 
to an "Ethiopian Origin ID Card" that grants them some of the rights and privileges of an Ethiopian national [42]. In 2007, the Government of Kenya established the Diaspora Affairs Directorate through the Ministry of Foreign Affairs. This office creates opportunities to mobilize diaspora to participate in the formulation of an overall diaspora engagement policy. As an example, the Government of Sierra Leone established the Directorate of Diaspora Affairs (Directorate) in the Ministry of Presidential and Public Affairs and the government has been explicit about its intention to utilize the diaspora network to fill gaps in the availability of medical doctors and nurses [43]. On the contrary, while many governments acknowledge the importance of diaspora engagement in development, many still lack the capacity to design effective policies and implement them on a meaningful scale [44].

\section{Discussion}

Throughout the collection of medical diaspora organizations from LMICs, some trends were noticed. Medical diaspora organizations tend to have three focuses: providing healthcare services, training, and when needed humanitarian aid to their home country; creating a social or professional network of migrant physicians (i.e., simply to bring together people with an ethnic and professional commonality); and supplying improved and culturally sensitive healthcare to the migrant population within the host country. Ethnic groups that did not necessarily have a large or well-established population within the host country came from countries where serious health problems still exist and were the most likely to have the first focus. Most of the diaspora groups from African countries fell into this category. Some groups from South/Southeast Asian countries like Bangladesh, as well as groups from select Middle Eastern and Central/Eastern European countries, also had this focus. Diaspora groups with a strong emphasis on the second focus were mainly intended to help new migrants feel welcome, make friends and successfully find jobs in the new country, as well as provide a forum for discussion of culturally relevant. In addition, these diaspora organizations are mainly used as a networking source to facilitate the exchange of information in the community, as opposed to providing services to their home countries [45]. Associations like these existed across diaspora groups from many continents, and mainly indicated a more casual, less explicitly purposed level of organization/ mission. Ethnic groups that had a large and long-standing population within the host country were most likely to have the third focus-that of providing improved care to the migrant population. Such medical diaspora groups are exemplified by the Chinese, Thai, Vietnamese and
Hispanic Americans, as well as Pakistanis and Indians in the United Kingdom.

In addition, there were other particular findings. Discovering which countries did not have medical diaspora groups was also sometimes interesting and may be instructive in identifying factors that contribute to an engaged diaspora. For example, though there are large migrant populations of South Africans across the world, no South African medical diaspora has been found. The same was true for Botswana and Namibia, although many other African countries, some with possibly with smaller migrant populations, had diaspora organizations. Crush et al. research on South African physicians in Canada shows that even though the South African medical diaspora in Canada who are mainly white, continue to assert their South African identity, they constitute a disengaged diaspora who are dissatisfied with the post-apartheid South African state [46]. Likewise, Chikanda and Dodson also showed that dissatisfaction with the political environment in the country of origin can have an adverse impact on the medical doctors' desire to engage positively with the country of origin [47]. Other countries without medical diaspora organizations included most of the Pacific Islands, Indonesia, Lao, Libya, Tunisia, Senegal, and others. Why these communities do not have diaspora organizations while so many others similar or smaller countries do, might be an informative and interesting question to ask. In the same manner, it was interesting to note that only a handful of organizations have produced peer-reviewed articles. Instead, most of the work they perform is distributed among the community as newsletters. According to the research, the most notable work done in the field of publication is by the Syrian American Society, which sponsors a peer-reviewed online medical journal [48] It is also equally important to note that many policy-makers may not have comprehensive knowledge of their own diaspora's development efforts and interests. Most, also, lack knowledge of models for diaspora engagement or of valuable lessons learned by other governments about working with diaspora. Thus, the health field related diaspora remains an underutilized resource and poorly-accounted-for factor in both health systems policy formulation and program implementation.

\section{Limitation}

The following limitations in our research analysis made a potential impact on our research findings. First, there was a lack of available data on diaspora organizations, which limited the scope of our analysis and our ability to recognize additional common characteristics between the diaspora organizations. We have tried to do a very thorough search to find medical diaspora organizations, but there could be organizations that we have not found. Second, there is no previous global-level research study 
published on this matter. Without a proper foundation on this topic, we created the first analysis of its kind. To overcome these limitations, new researches are needed on medical and other health-related diaspora associations and their link to building various components of the health systems in LMIC. Third, we focused only on Anglophone recipient countries and did not include Francophone, Lusophone, Arabic speaking or other destination countries. Fourth, we acknowledge that there may be the possible existence of some medical diaspora organizations without an online presence. Finally, the authors believe more in-depth research is warranted to develop metrics to measure the effectiveness of medical diaspora organizations.

\section{Conclusions}

Newland and Patrick identified the role of diasporas' as supporting groups who pursue charitable enterprises and that their contribution has expanded beyond just investment inflows and remittances [49]. Diasporas are now viewed as important agents of change by countries of origin, donor agencies, and the international community. The skills of the diasporas can be tapped by establishing knowledge exchange networks. Some initiatives include mentor-sponsor programs, joint research projects, peer reviewer mechanisms, virtual return (through distance teaching and e-learning), and short-term visits and assignments. To increase the benefits of these activities, countries will have to map the gaps that they require to be filled in their health systems, survey the human resources available in their diasporas, create active networks, and develop specific activities and programs.

Despite this progress, work must continue to build the evidence base to develop the knowledge and capacity of engaging diaspora effectively at scale in a systematic and sustainable way. Countries and development partners should emphasize evaluation of efforts and mechanisms to share "what works" on a global platform to contribute to the global dialog. As we move forward, it will be increasingly important to utilize this evidence to build strategic partnerships between states, international organizations, civil society and private sector to create a framework for medical diaspora engagement and facilitate a transfer of resources and knowledge sharing.

\section{Abbreviations}

DNA: Diaspora Networks Alliance; HRH: Human Resources for Health; IDEA: International Diaspora Engagement Alliance; LMIC: Low- and middleincome countries; MDGs: Millennium Development Goals; SDG: Sustainable Development Goals; WHO: World Health Organization

\section{Acknowledgements}

The authors acknowledge Sinit Mehtsun and Kristen Korhumel who helped in researching for data during the early phase of the paper.

\section{Authors' contributions}

SF had the idea for the study, designed the study, and wrote the paper. CP and $\mathrm{Al}$ helped researching and writing the paper. All authors collected and analyzed data, and revised and approved the report. The corresponding author had full access to all the data in the study and had final responsibility for the decision to submit for publication. All authors read and approved the final manuscript.

\section{Funding}

Funding information is not applicable. No funding was received.

Availability of data and materials

The data is available from the corresponding author.

Ethics approval and consent to participate

Not applicable.

\section{Consent for publication}

Not applicable. No individual person's data in any form used.

\section{Competing interests}

The authors declare that they have no competing interests.

\section{Author details}

${ }^{1}$ Milken Institute School of Public Health, The George Washington University, 950 New Hampshire Ave. NW, Washington DC 20052, United States of America. 2Lenoir-Rhyne University, 625 7th Ave NE, Hickory, NC 28601, United States of America.

Received: 6 March 2019 Accepted: 4 July 2019

Published online: 15 July 2019

\section{References}

1. Sheffer G. In: Sheffer G, editor. Modern diasporas in international politics. London and Sydney: Croom Halm; 1986. p. 1-5.

2. The World Bank: Remittances to developing countries to stay robust this year, despite increased deportations of migrant workers, says WB. http://www.worldbank.org/en/news/press-release/2014/04/11/ remittances-developing-countries-deportations-migrant-workers-wb (2014). Accessed 6 May 2019.

3. Baumann M. Diaspora: Genealogies or semantics and transcultural comparison. Numen. 2000:47(3):313-37.

4. The United Nations: Future we want - outcome document. https:// sustainabledevelopment.un.org/futurewewant.html. (2018). Accessed 21 Feb 2019.

5. Chen L, Evans T, Anand S, Boufford Jl, Brown H, Chowdhury M, et al. Human resources for health: overcoming the crisis. The Lancet. 2004;364(9449): 1984-90 https://doi.org/10.1016/S0140-6736(04)17482-5.

6. Travis P, Bennett S, Haines A, Pang T, Bhutta Z, Hyder AA, et al. Overcoming health-systems constraints to achieve the Millennium Development Goals. The Lancet. 2004;364(9437):900-6.

7. The United Nations: Contributions of migrants and diasporas to all dimensions of sustainable development, including remittances and portability of earned benefits. https://refugeesmigrants.un.org/sites/default/ files/ts4_issuebrief.pdf (2017). Accessed 6 May 2019.

8. Lowell BL, Findlay AM: Migration of highly skilled persons from developing countries: Impact and policy responses. http://www.ilo.org/public//english/ protection/migrant/download/skmig-sr.pdf (2001). Accessed 6 May 2019.

9. World Health Organization: Migration of health workers: WHO code of practice and the global economic crisis. https://www.who.int/hrh/migration/14075_ MigrationofHealth_Workers.pdf (2014). Accessed 9 May 2019.

10. Mullan F. The metrics of the physician brain drain. New Engl J Med. 2005; 353(17):1810-8.

11. The World Bank: world bank country and lending groups. https:// datahelpdesk.worldbank.org/knowledgebase/articles/906519 (2019). Accessed 6 May 2019.

12. The American Association for the Advancement of Science: List of scientific diaspora organizations. http://www.aaas.org/sites/default/files/DiasporaList_ 0.pdf (2015). Accessed 21 Feb 2019. 
13. Wojczewski S, Poppe A, Hoffmann K, Peersman W, Nkomazana O, Pentz S, et al. Diaspora engagement of African migrant health workers - examples from five destination countries. Global health action. 2015;8.

14. Abdalla FM, Omar MA, Badr EE. Contribution of Sudanese medical diaspora to the healthcare delivery system in Sudan: exploring options and barriers. Hum Resour Health. 2016;14(Suppl 1):28.

15. Nwadiuko J, James K, Switzer GE, Stern J. Giving Back: a mixed methods study of the contributions of US-based Nigerian physicians to home country health systems. Globalization and health. 2016;12:1.

16. Nigerian American Medical Foundation International: Our story so far... and our pledge to accountability and transparency. https://namfi.org (2018). Accessed 21 Feb 2019

17. Sudanese Medical Association UK and Ireland: About SMA (UK\&l). https://www. facebook.com/groups/sma.ukandire/about (2018). Accessed 21 Feb 2019.

18. Ethiopian North American Health Professionals Association: Mission \& Vision. http://www.enahpa.org/about-us/mission-vision (2018). Accessed 21 Feb 2019.

19. Ghana Physicians and Surgeons Foundation of North America: History. https://www.ghanaphysicians.org/history (2017). Accessed 21 Feb 2019.

20. The American Association of Physicians of Indian Origin: About AAPI. https://aapiusa.org/about-us/about-aapi (2018). Accessed 21 Feb 2019.

21. Afghan Medical Professionals Association of America: Our mission. http:// www.ampaa.org/Our-Mission.html (2018). Accessed 21 Feb 2019.

22. Albanian American Medical Society: History. https://www.albamedsociety. org/history (2018). Accessed 21 Feb 2019.

23. Armenian American Medical Society: About Us. https://aamsc.org/about-us (2018). Accessed 21 Feb 2019.

24. Ukrainian Medical Association of the United Kingdom: About UMAUK. http://www.umauk.com/ArticleView.aspx?name=About\%20UMAUK\&hidden= y (2018). Accessed 21 Feb 2019

25. Romanian Medical Association of America: About RMAA. https://www. facebook.com/Romanian-Medical-Association-of-America-250257948368293 (2018). Accessed 21 Feb 2019.

26. Mullan F, Frehywot S, Omaswa F, Buch E, Chen C, Greysen SR, et al. Medical schools in sub-Saharan Africa. The Lancet. 2011:377(9771):1113-21.

27. People to People: Message From Founder. https://p2pbridge.wordpress. com/message-from-founder (2014). Accessed 21 Feb 2019.

28. Medical Association of Nigerians Across Great Britain: About Us. http://www. mansag.org/about-us (2018). Accessed 21 Feb 2019.

29. The Association of Nigerian Physicians in the Americas: Mission + Vision. https://anpa.org/mission-vision (2018). Accessed 19 Feb 2019.

30. Nepalese Doctors' Association UK: About Us. http://ndauk.org.uk/index.php/ history (2018). Accessed 21 Feb 2019.

31. America Nepal Medical Foundation: History. https://www.anmf.org/historyof-anmf (2018). Accessed 21 Feb 2019.

32. Bangladesh Medical Association of North America: About BMANA. https:// www.bmana.org/about-us/about-bmana (2018). Accessed 21 Feb 2019.

33. Syrian American Medical Society Foundation: About SAMS Foundation. https://www.sams-usa.net/who-we-are (2018). Accessed 21 Feb 2019.

34. Burmese Doctors and Dentists Association UK: About BDDAUK. https:// www.facebook.com/pg/BDDAUK/about/?ref=page_internal (2018). Accessed 21 Feb 2019.

35. British Iranian Medical Association: Home - BIMA. https://www.facebook. com/BIMAUK (2018). Accessed 21 Feb 2019.

36. Gamlen A. Diaspora institutions and diaspora governance. International Migration Review. 2014;48:S180-217.

37. Agunias DR, Newland K. Developing a road map for engaging diasporas in development: a handbook for policymakers and practitioners in home and host countries: Taylor \& Francis; 2012.

38. Government of India: Diaspora Engagement. https://www.mea.gov.in/ diaspora-engagement.htm (2018). Accessed 21 Feb 2019.

39. Lum K. India's engagement with its diaspora in comparative perspective with China: European University Institute; 2012.

40. African Development Bank Group: AfDB migration activities. https://www.afdb. org/en/topics-and-sectors/initiatives-partnerships/migration-and-developmentinitiative/afdb-migration-activities (2018). Accessed 21 Feb 2019.

41. Mohamoud A. Building institutional cooperation between the diaspora and homeland governments in Africa: the cases of Ghana. Nigeria, Germany, USA and the UK: African Diaspora Policy Centre; 2010.

42. The Ministry of Foreign Affairs of Ethiopia: About MFA Ethiopia. https:// www.facebook.com/pg/MFAEthiopia/about/?ref=page_internal (2018). Accessed 21 Feb 2019.
43. Government of Sierra Leone: Diaspora Affairs. https://diasporaaffairs.gov.sl (2018). Accessed 21 Feb 2019.

44. African Development Bank: Leveraging human capacity and financing from the diaspora. https://www.afdb.org/fileadmin/uploads/afdb/Documents/ Publications/AfriCaDev\%20Brief\%20DIASPORA.pdf (2011). Accessed 21 Feb 2019.

45. Standford University: African collections. http://library.stanford.edu/areas/ african-collections (2018). Accessed 21 Feb 2019.

46. Crush J, Chikanda A, Pendleton W. The Disengagement of the South African Medical diaspora in Canada. Journal of Southern African Studies. 2012;38(4):927-49.

47. Chikanda A, Dodson B. Medical migration from Zimbabwe: Towards new solutions. Geographies of health and development. 2015:281-95.

48. Georgia Association of physicians of indian heritage: about GAPI. http:// gapi.org/about-gapi-2 (2018). Accessed 21 Feb 2019.

49. Newland K, Patrick E. Beyond remittances: the role of diaspora in poverty reduction in their countries of origin, a scoping study by the Migration Policy Institute for the Department of International Development. Migration Policy Institute. 2004.

\section{Publisher's Note}

Springer Nature remains neutral with regard to jurisdictional claims in published maps and institutional affiliations.
Ready to submit your research? Choose BMC and benefit from:

- fast, convenient online submission

- thorough peer review by experienced researchers in your field

- rapid publication on acceptance

- support for research data, including large and complex data types

- gold Open Access which fosters wider collaboration and increased citations

- maximum visibility for your research: over $100 \mathrm{M}$ website views per year

At $\mathrm{BMC}$, research is always in progress.

Learn more biomedcentral.com/submissions 